\title{
MULTI-ROTOR UNMANNED AERIAL VEHICLES (UAVS) AND HIGH-RESOLUTION COMPACT DIGITAL CAMERAS: A PROMISING NEW METHOD FOR MONITORING CHANGES TO SURFACE KARST RESOURCES
}

\author{
MULTIROTORSKA ZRAČNA PLOVILA BREZ POSADKE (UAV) \\ IN KOMPAKTNE DIGITALNE KAMERE VISOKE LOČLJIVOSTI: \\ OBETAVNA NOVA METODA ZA SPREMLJANJE SPREMEMB \\ POVRŠINSKIH KRAŠKIH POJAVOV
}

\author{
Carolyn L. RAMSEY' ${ }^{1}$, Paul A. GRIFFITHS ${ }^{2}$ \& Timothy R. STOKES 3
}

\begin{abstract}
UDC 528.715:629.735(711)

551.435.8:528.715(711)

Carolyn L. Ramsey, Paul A. Griffiths \& Timothy R. Stokes: Multi-rotor unmanned aerial vehicles (UVAs) and high-resolution compact digital cameras: a promising new method for monitoring changes to surface karst resources

In the course of doctoral research, the authors required a quick and accurate means of documenting the real-time state of surface karst features at a variety of scales in remote and challenging field conditions. The main difficulty was finding an aerial platform that was 1) consistently effective; 2) versatile; and 3) relatively inexpensive. High resolution vertical images obtained during recreational use of a small multi-rotor unmanned aerial vehicle (UAV) seemed to have the potential to answer this need. Using five case studies, the authors examine the potential of these images for mapping, documenting, and monitoring changes to surface karst resources following forestry-related activities in the coastal temperate rainforest of British Columbia (B.C.). Possible applications, strengths and limitations of this technology are discussed. The authors conclude that mini quadcopter UAVs equipped with high-resolution compact digital cameras are a promising and cost-effective new tool for karst scientists and karst managers.
\end{abstract}

Key words: Unmanned aerial vehicle (UAV), quadcopter, vertical aerial photography, monitoring, karst, British Columbia.
Povzetek

UDK 528.715:629.735(711) 551.435.8:528.715(711)

Carolyn L. Ramsey, Paul A. Griffiths \& Timothy R. Stokes: Multirotorska zračna plovila brez posadke (UAV) in kompaktne digitalne kamere visoke ločljivosti: obetavna nova metoda za spremljanje sprememb površinskih kraških pojavov

$\mathrm{V}$ okviru doktorskih raziskav, avtorji zahtevajo hiter in točen način dokumentiranja stanja površinskih kraških pojavov različnih velikosti $\mathrm{v}$ realnem času ter $\mathrm{v}$ oddaljenih in zahtevnih terenskih pogojih. Glavna težava je bila v iskanju letalne naprave, ki bi bila 1) konsistentno učinkovita; 2) vsestranska; in 3) relativno poceni. Ugotovili so, da imajo vertikalne slike visoke ločljivosti pridobljene med prostočasnimi aktivnostmi z multirotorjem brez posadke (UAV) potencial, ki bi odgovarjale zahtevanim potrebam. $\mathrm{Z}$ uporabo petih študijskih primerov so avtorji preučili potencial pridobljenih posnetkov za kartiranje, dokumentiranje in spremljanje sprememb kraških površinskih pojavov povezanih z gozdarskimi dejavnostmi v predelih obalnega deževnega gozda zmernih širin v Britanski Kolumbiji (B.C.). Razpravljali so o možnih aplikacijah, prednostih ter omejitvah te tehnologije. Avtorji ugotavljajo, da je mini Quadkopter UAV opremljen s kompaktno kamero visoke ločljivosti stroškovno obetaven in da je to učinkovito novo orodje za krasoslovce in upravljavce krasa.

Ključne besede: letalna naprava brez posadke (UAV), quadkopter, vertikalna zračna fotografija, monitoring, kras, Britanska Kolumbija.

\footnotetext{
${ }^{1}$ Carolyn L. Ramsey: PhD student, University of Nova Gorica; Honorary Research Associate, Vancouver Island University, 900 Fifth Street, Nanaimo, British Columbia, Canada V9R 5S5, e-mail: clramsey@shaw.ca

2 Paul A. Griffiths, 544 Springbok Road, Campbell River, B.C. Canada V9W 8A2, e-mail: pgriff@shaw.ca

${ }^{3}$ Timothy R. Stokes, PGeo, PhD, Earth Science Department, Vancouver Island University, 900 Fifth Street, Nanaimo, B.C. Canada V9R 5S5, e-mail: tim.stokes@viu.ca
}

Received/Prejeto: 14.08 .2013 


\section{INTRODUCTION}

Adequate protection and management of karst resource features has been a major concern in the coastal temperate rainforests of British Columbia (B.C.) (Griffiths 2013). Research and monitoring of karst resources in this region are often hampered by terrain conditions, the distances involved in getting to and from field sites, and a scarcity of funding. Long hours of painstaking ground-based surveys in rugged and remote locations are often required to adequately document baseline conditions or the nature and scale of disturbance events. Affordable new technologies which optimize the use of field time while lowering the cost of study are therefore of great interest. by the Provincial Government on behalf of the public. Primary access to all of the karst sites was by road. Images thus obtained are presented in the case studies, below.

The legal requirements for use of UAVs differ from country to country. Recreational flying of commercially available quadcopter UAVs in Canada does not require any special licence or training if the vehicle weighs less that $35 \mathrm{~kg}$. Nevertheless, established safe model aircraft flying rules and standards must be respected at all times and in all locations in Canada, including those most remote. ${ }^{1}$

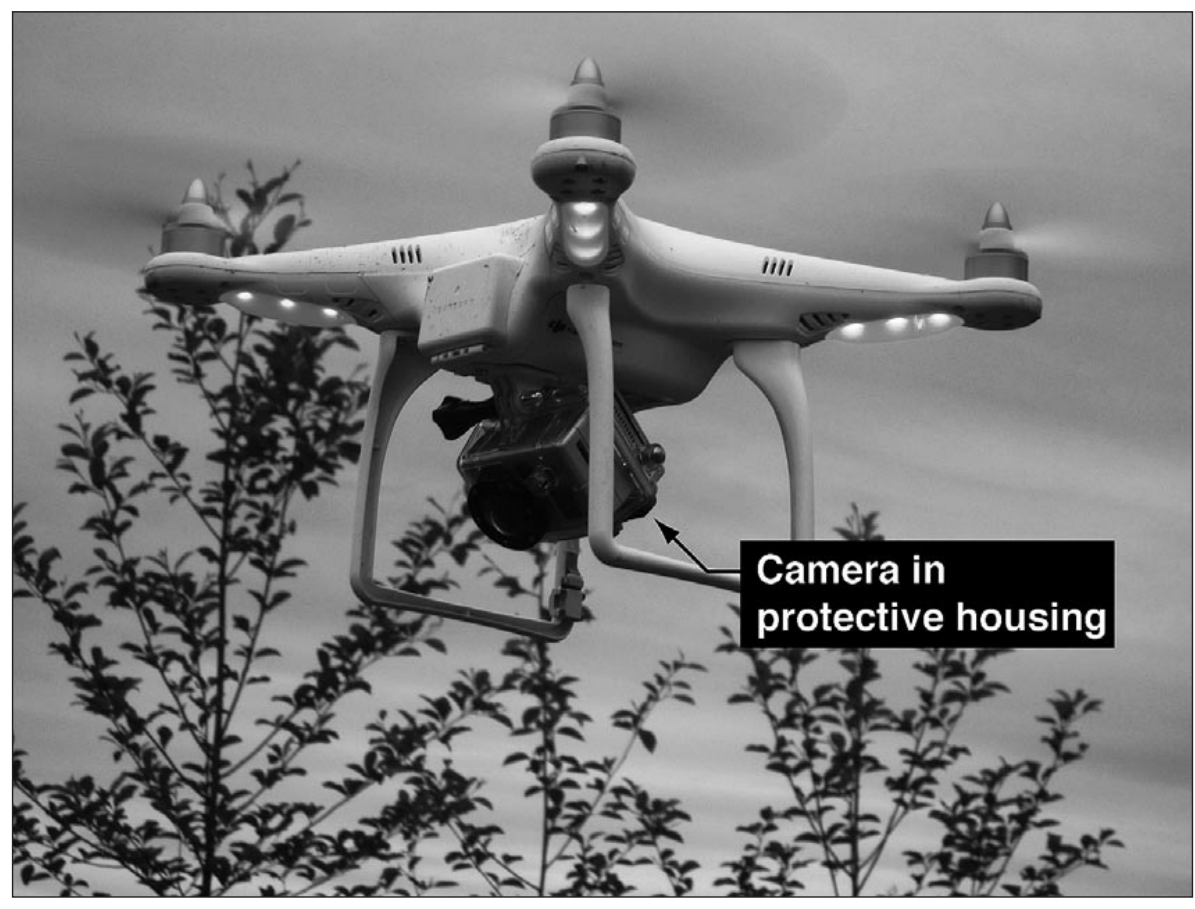

Fig. 1: Mini multi-rotor UAVs equipped with compact high-resolution cameras are inexpensive and have the potential to increase data collection and monitoring capacity for karst researchers and managers (Photo: C.L. Ramsey).

Multi-rotor unmanned aerial vehicles (UAVs) equipped with high-resolution compact digital cameras have the potential to revolutionize the monitoring of surface karst resources in coastal B.C. because they permit rapid, accurate and inexpensive collection of highresolution aerial images at different scales. The resulting images provide permanent records of the condition of a karst site or feature at a given point in time. These images can be used to derive scale-appropriate measurements of the surface elements of karst resource features at time intervals defined by the karst researcher or manager.

The authors flew an inexpensive UAV quadcopter at a number of northern Vancouver Island karst sites, obtaining low-altitude aerial photography in typical field conditions. The karst sites were located on land managed

\section{STUDY AREA DESCRIPTION}

Vancouver Island is situated on Canada's west coast. The island is $450 \mathrm{~km}$ long and has a total area of about $32,000 \mathrm{~km}^{2}$. The general climate regime is temperate oceanic mesothermal with some regional and local variations related to physiography (Moore et al. 2010). Vancouver Island falls within the northern temperate coastal rainforest biome. The dominant vegetation is evergreen conifers.

\footnotetext{
${ }^{1}$ Flying any quadcopter in Canada for commercial purposes, profit or reward requires a Special Flight Operation Certificate from Transport Canada. The federal agency has been proactively addressing the rapidly evolving use of UAVs in Canada, attempting to ensure the highest standards of safety while enabling commercial UAV use through a formal approval process.
} 
About $4 \%$ of Vancouver Island is underlain by bedrock that has the potential to form karst. This encompasses a geographic area of about $1,200 \mathrm{~km}^{2}$. Quatsino Formation limestone represents the most important bedrock unit for hosting karst as well as the most extensive of three limestone units on Vancouver Island (Fischl 1992).

The primary land use activity affecting karst in coastal B.C. and on Vancouver Island is industrial forestry. Most of the timber harvesting carried out on the karst has been firstpass logging of old-growth forest stands using the clearcut harvest method (Griffiths \& Ramsey 2006). Clearcutting with $10 \%$ of the total cutblock area timber left standing as reserve patches is the most common silvicultural system used in B.C. at present (Vyse et al. 2010). Other land use activities on Vancouver Island on or near karst include mining, quarrying and hydroelectric development.

\section{PROBLEM STATEMENT}

The natural conditions of coastal B.C. impose certain limitations on karst research and monitoring activities. Most of the karst on Vancouver Island is located in remote areas. Distances between karst sites of research or management interest can be great. The sites themselves are often rugged and difficult to move about in, especially when covered with logging debris, tree windthrow or dense vegetation.

Stereoscopic aerial photos and satellite images for many areas of interest are commercially available or can be obtained online from Google Earth, but image resolution is often insufficient for the detection of smaller karst features or for use in site evaluation to assist research or management objectives. Additionally, the high-altitude imagery is sometimes compromised by cloud or snow cover. The maximum resolution provided by commercial satellites is commonly $60 \mathrm{~cm}$ per pixel (Murray et al. 2012).

Helicopters make it possible to reduce travel time to and between remote karst sites, and to obtain lower-altitude aerial images, but they remain expensive to charter. ${ }^{2}$ Even with sufficient budgeting capacity, helicopters are not always ideal for some research and monitoring applications in B.C.'s coastal temperate rainforest karst. Low ceilings can limit accessibility to some karst sites or altogether obscure features on the ground from aerial views. Forest vegetation, rugged topography and weather conditions can also limit where and when helicopters can

${ }^{2}$ Hourly rates can range from $\$ 1,250$ to $\$ 1,750$ USD for a Bell 206 Jet Ranger and Eurocopter AStar B Model, respectively. manoeuvre or land safely. Few helicopters are equipped with external camera mounts for accurate vertical photography, and cameras cannot penetrate dense forest canopy even if these mounts are present.

Ground-based travel to karst sites is more affordable than helicopters, but the slower traveling time limits the number of sites that can be visited in a given day. Finally, ground-based fieldwork is also limited by line of sight and cannot always provide overviews of site conditions unless high promontories or photopoints with unobstructed views are available.

Though remote sensing methods such as LiDAR (Light Detection and Ranging) may allow for some characterization of karst sites under dense canopy cover, the ranging data are either publicly unavailable at present or unavailable at the resolutions required by some of the inspection tasks. Moreover, remote sensing imagery or aerial photography may be dated and may not, therefore, accurately represent the current state of karst sites.

UAVs have the potential to circumvent many of the preceding issues. With a small camera mounted on an aerial platform, it is possible to obtain high-resolution images of a site on any particular day inexpensively and to rapidly examine an area greater than can be walked in a day. In many cases, a vertical view of a site is preferred over an angled terrestrial view, which may not accurately depict the overall site conditions (e.g., areal distribution of logging debris). While such images cannot replace walking on the ground and site verification, they do serve as a useful tool to assist and enhance field work.

\section{METHODS AND EQUIPMENT}

\section{THE QUADCOPTER}

The multi-rotor UAV aerial platform used by the authors is classified as a radio-controlled mini quadcopter equipped with a compact digital camera. The quadcopter can be defined as a four-rotor helicopter (Bošnak et al. 2012). It uses four brushless and gearless electrical mo- 
tors, has no mechanical components, and is therefore virtually maintenance-free (Roßmann 2009).

The model of quadcopter under study was a DJI Phantom Quadcopter. This quadcopter is powered by a $2200 \mathrm{~mA}$ LiPo rechargeable battery pack providing up to 15 minutes of flight time without the camera payload and 8-10 minutes with the camera. Extra battery packs and a charging regimen using a vehicle 12 volt battery and a power inverter were available for use as needed. The radio controller is based on a $2.4 \mathrm{GHz}$ frequency and capable of a range of at least $300 \mathrm{~m}$. When flown in GPS mode, this quadcopter has autonomous landing and return-to-home capability in case of a low battery or loss of radio signals.

Tab. 1: Key technical specifications of DJI Phantom Quadcopter.

\begin{tabular}{ll}
\hline $\begin{array}{l}\text { Hovering accuracy in GPS } \\
\text { mode }\end{array}$ & $\begin{array}{l}\text { Vertical: } \pm 0.8 \mathrm{~m} \text {; horizontal: } \\
\pm 2.5 \mathrm{~m}\end{array}$ \\
\hline Max tilt angle & $45^{\circ}$ \\
\hline $\begin{array}{l}\text { Maximum ascent/descent } \\
\text { speed }\end{array}$ & $\pm 6 \mathrm{~m} / \mathrm{s}$ \\
\hline Max flight velocity & $10 \mathrm{~m} / \mathrm{s}$ \\
\hline Battery type, rechargeable & $2200 \mathrm{mAh} \mathrm{LiPo}$ \\
\hline $\begin{array}{l}\text { Transmitter frequency } \\
\text { Minimum communication } \\
\text { distance }\end{array}$ & $2.4 \mathrm{GHz} \mathrm{ISM}$ \\
\hline $\begin{array}{l}\text { Diagonal distance (motor } \\
\text { center to motor center) }\end{array}$ & $300 \mathrm{~m}$ \\
\hline \begin{tabular}{l} 
Take-off weight \\
\hline
\end{tabular} & $<1000 \mathrm{~g}$ \\
\hline
\end{tabular}

\section{THE CAMERA}

For image acquisition, the quadcopter was equipped with a GoPro HD Hero2 high-resolution camera in a polycarbonate waterproof housing. At $230 \mathrm{~g}$, this compact digital camera, including battery and protective housing, is well within the payload capacity of the DJI Phantom Quadcopter. The quadcopter frame is purposely designed with a mount for use with this camera. The camera can record high-definition (HD) video at a maximum of $1920 \times 1080$ screen resolution, or still imagery at 11,8 or 5 megapixels. ${ }^{3}$ The camera was used in time-lapse photo mode for our field trials, but it can also be operated in continuous $\mathrm{HD}$ video mode at a variety of resolutions, although video cannot be recorded during still image capture.

\section{FLIGHT PARAMETERS}

The onboard GPS navigation system is used to maintain a hover position, and allows the quadcopter to return

${ }^{3}$ The recording of HD video can be used to optimize spatial coverage of a karst site. 'home' if the radio signal is lost. The quadcopter was flown manually in GPS mode to capture the particular scenes or elements of interest at the sites. Although the radio control range is potentially greater than $300 \mathrm{~m}$, for safety reasons the quadcopter was not flown higher than $120 \mathrm{~m}$ above the ground and was kept within sight at all times. ${ }^{4}$

Tab. 2: Key technical specifications of the GoPro Hero2 camera.

\begin{tabular}{ll}
\hline Optical sensor type & CMOS \\
\hline $\begin{array}{l}\text { Effective maximum photo } \\
\text { resolution }\end{array}$ & $11 \mathrm{MP}$ \\
\hline Photo recording format & $\mathrm{JPEG}$ \\
\hline Maximum view angle & $170^{\circ}$ \\
\hline Lens aperture & $\mathrm{F} / 2.8$ \\
\hline Supported memory cards & $\mathrm{SD}, \mathrm{SDHC}$ \\
\hline Battery type, rechargeable & $1100 \mathrm{mAh} \mathrm{Li-ion}$ \\
\hline $\begin{array}{l}\text { Dimensions without protective } \\
\text { housing }\end{array}$ & $58.4 \times 44.5 \times 31.8 \mathrm{~mm}$ \\
\hline Camera and battery & $100 \mathrm{~g}$ \\
\hline $\begin{array}{l}\text { Camera, battery and protective } \\
\text { housing }\end{array}$ & $230 \mathrm{~g}$ \\
\hline
\end{tabular}

All of the aerial images were captured with the camera pointed downward at the nadir, and were collected in time lapse photo mode with an interval setting of one image every 2 seconds at the maximum resolution of 11 megapixels. The memory card has a $16 \mathrm{~GB}$ capacity, allowing for the storage of up to 1600 still images at the maximum resolution. Saved images from the installed SD card were downloaded periodically to a laptop in the field to verify image quality and the area of the karst site covered. If the recorded images or photo alignments were unsatisfactory, the route was reflown. The camera operation by itself was limited to approximately 2.5 hours between battery charges using a laptop USB port.

In some cases, a $50 \mathrm{~cm}$ diameter white plastic disk with a black cardinal cross and indication of true north position was used as a control point to measure the camera height above the ground at a target. The disk, used previously in ground surveys, facilitated the setting of camera height above the ground as well as the orientation of the acquired image with respect to true north in any subsequent image processing.

\footnotetext{
${ }^{4}$ A first-person viewing (FPV) system can be used with a quadcopter UAV to facilitate flights beyond the visible range. The cost of FPV can add 350-400 USD to overall costs of the aerial platform.
} 


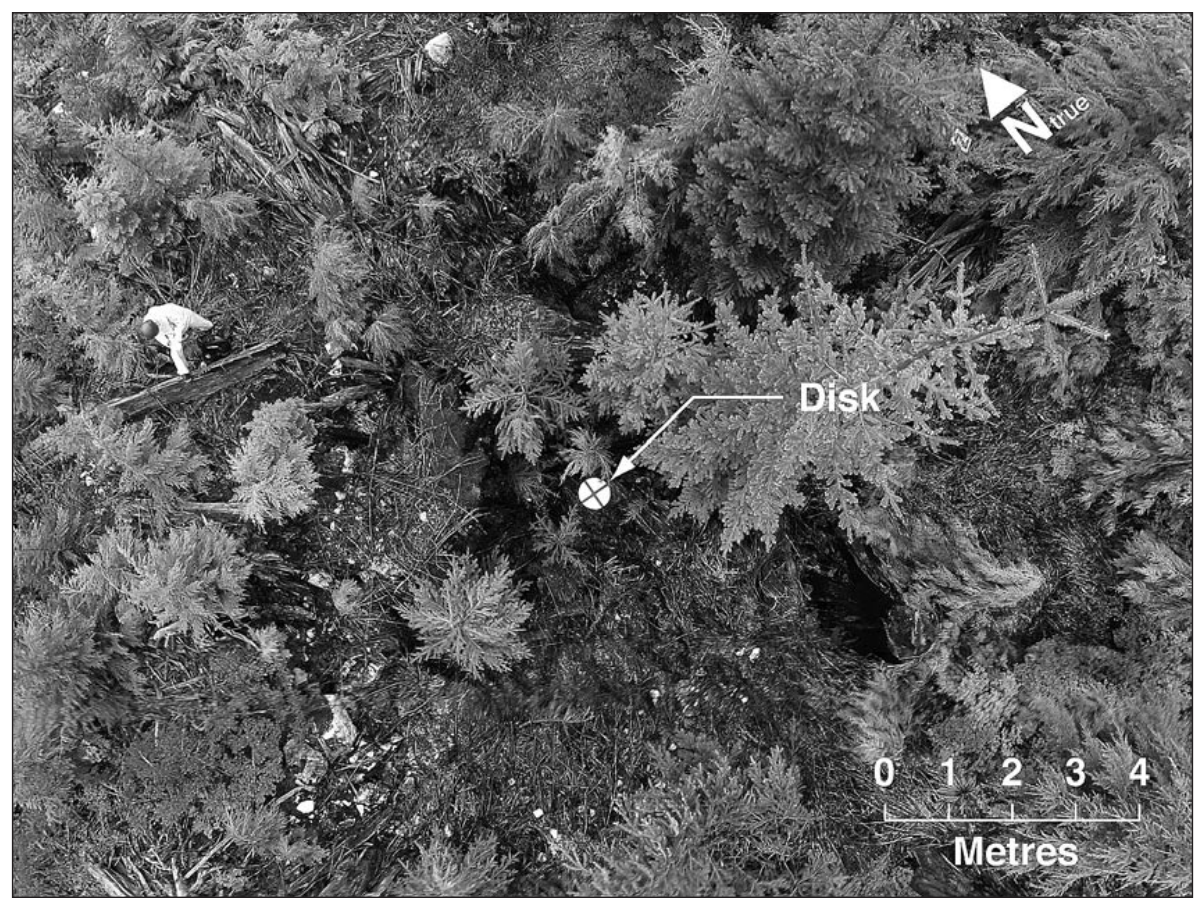

Fig. 2: A white $50 \mathrm{~cm}$ diameter disk with a black cross indicating the cardinal directions can be used to measure the camera height above the ground at a target. The disk, used in groundbased field work, is easily visible in the images acquired with the $U A V$.

\section{FIVE CASE STUDIES: FIELD TRIALS USING THE QUADCOPTER AERIAL PLATFORM}

The following case studies illustrate how UAV-assisted low-altitude aerial photography has the potential to overcome some of the barriers to karst monitoring, research and management initiatives.

\section{CASE STUDY 1: RETENTION PATCH}

The Retention Patch is a karst site with a small karst window at its core. The old-growth forest around the feature was logged ca. 2010. A retention patch $20-30 \mathrm{~m}$ wide comprised of $100 \%$ standing timber was established around the karst window as a management measure. In the intervening years, the standing timber 'reserve' began to blow down, the upturned root masses of the windthrown trees exposing well-developed epikarst. The authors spent two person-days surveying and mapping the karst window and the distribution of windthrown trees on 06 October 2011. The results are shown in Fig. 3. The authors returned to the Retention Patch site on with the quadcopter aerial platform and sent it aloft for approximately 3-5 minutes to acquire aerial images. A representative aerial photo is shown in Fig. 4A, with superimposition of the results of the two person-day survey.

One can rapidly delineate the downed trees and many of the areas of exposed epikarst using the highresolution aerial images acquired with the quadcopter
UAV. These data were equivalent to, or more accurate than, those acquired by the ground-based survey methods, and the images were collected in a fraction of the time. Ground-truthing would have been required to ascertain the decay classes of the downed wood. It was also noted that not all of the exposed epikarst is visible from the air based on the altitudes and routes flown. Nevertheless, this case study illustrates how a mini multi-rotor UAV flown at low altitudes is able to quickly capture accurate data related to disturbance events at karst sites in relatively inaccessible and remote areas.

\section{CASE STUDY 2: Q1 DOLINE AND THE DOLINE GROUP}

The Q1 doline measures $9.87 \mathrm{~m}$ long, $8.47 \mathrm{~m}$ wide, and $2.89 \mathrm{~m}$ deep. It is nested along with eight other topographical lows within a larger elongate karst depression. During an initial field visit, a forest road had been built against the east rim of the doline and some mature second-growth timber on that side of the feature had been felled in the process. Full-scale timber harvesting operations had not yet begun. The doline rim, adjacent road and sideslope profiles were surveyed on the ground during the initial field visit. Standing trees and downed trees in and around the doline were also 


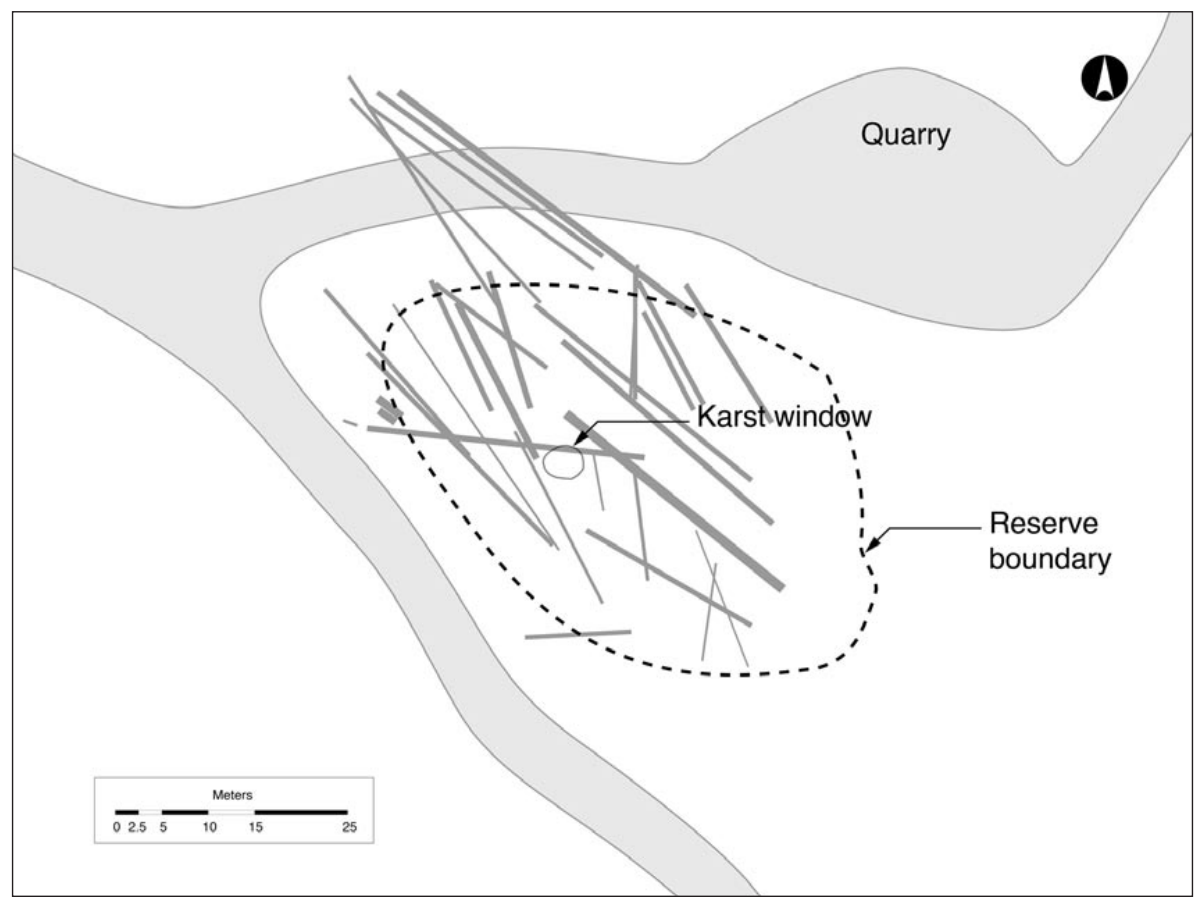

Fig. 3: Planimetric map of the windthrown trees at the Retention Patch, produced from data collected over 2 person-days in the field in October 2011. The dashed black line shows the approximate boundary of the tree retention area.

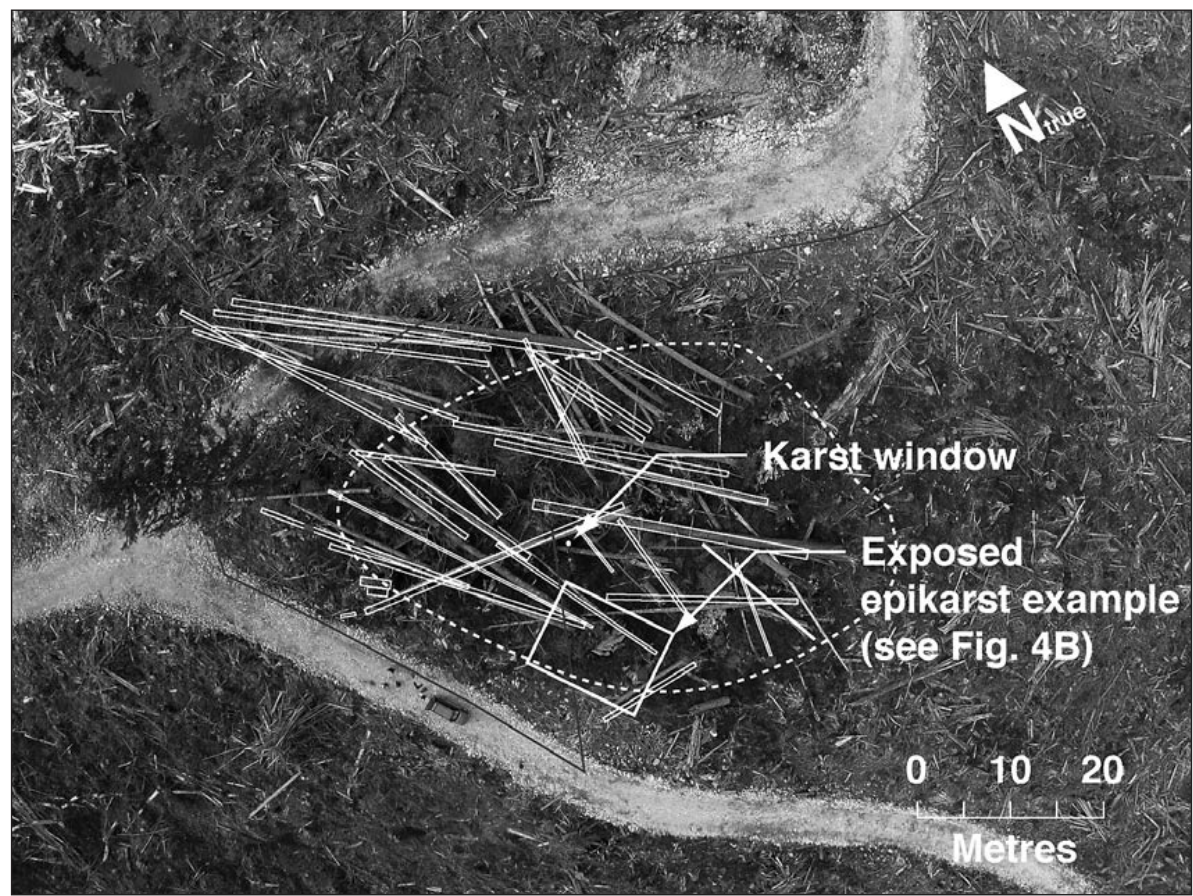

Fig. 4A: UAV image of the Retention Patch with the October 2011 survey of the windthrown trees superimposed. The dashed white line indicates the approximate boundary of the tree retention area.

surveyed and rough estimates of percent coverage of surface substrates were noted. Additionally, disturbance indicators used by B.C.s Forest and Range Evaluation Program (FREP) for this karst feature type, were evaluated and recorded.

Fourteen other dolines in a cluster were located in a stand of mature second-growth timber about $500 \mathrm{~m}$ from the Q1 doline. This second set of dolines, referred to here as the 'Doline Group' (Fig. 7), and some other minor karst features, were tied into known points on the ground using overland survey techniques on 10 June 2012 and then plotted on a 1:1000 scale planimetric map. It took approximately one person-day to survey these karst features to establish their geographical locations and spatial distribution, and to document their pre-harvest condition using ground-based oblique photography. 


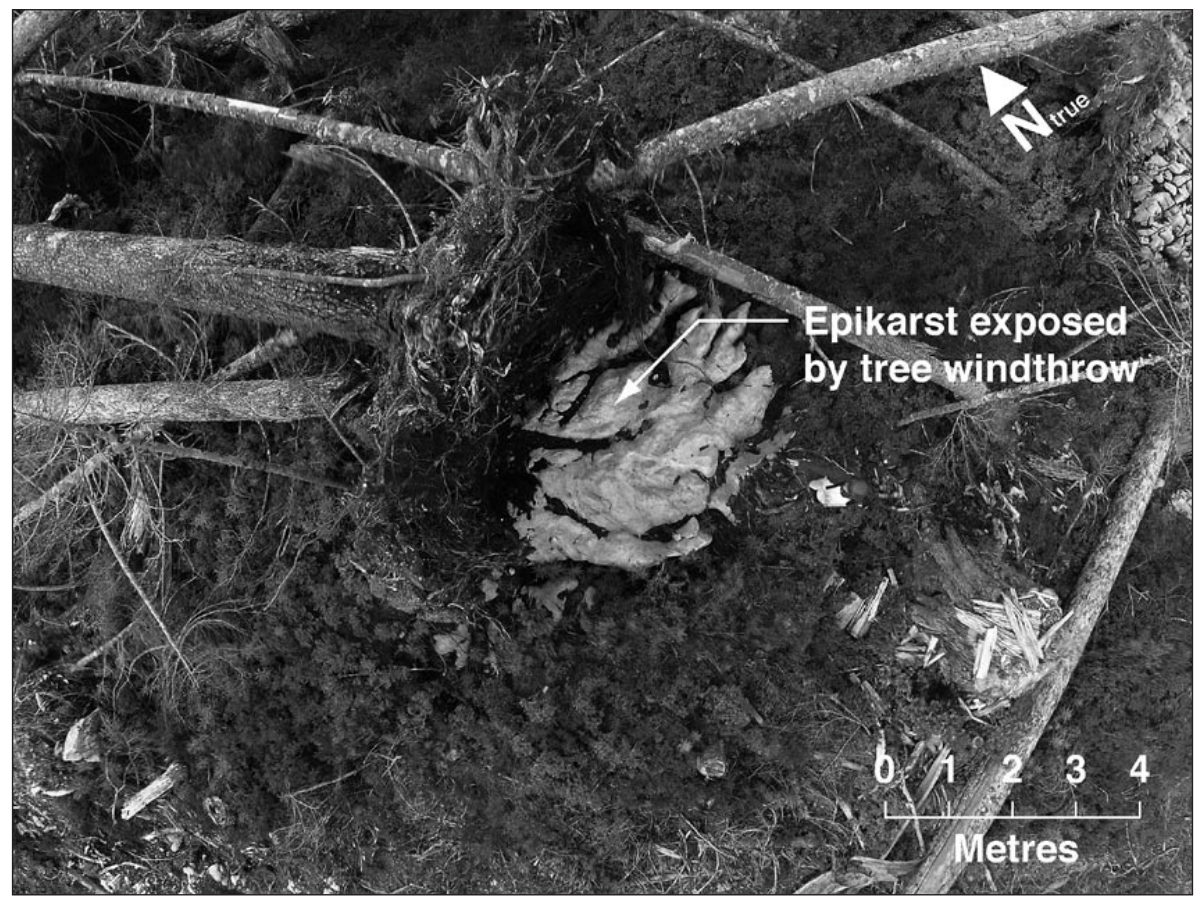

Fig. 4B: Low-altitude UAV image of the epikarst in the tree retention area exposed by the tree windthrow.

The authors returned to the two karst sites with the camera-equipped quadcopter after timber harvesting operations had been completed. The aerial platform was sent aloft to acquire images of the Q1 doline followed by the Doline Group at the second site.

Case study \#2 illustrates how low-altitude aerial imagery acquired by a quadcopter UAV can be used to doc- ument accurately and rapidly any post-harvest changes such as ground disturbance, logging debris, machine trails, retained understory vegetation and replanting at karst sites.

Field trials at the Q1 Doline and Doline Group sites also show the potential for the multi-rotor UAVs to be used within B.C.'s Forest and Range Evaluation

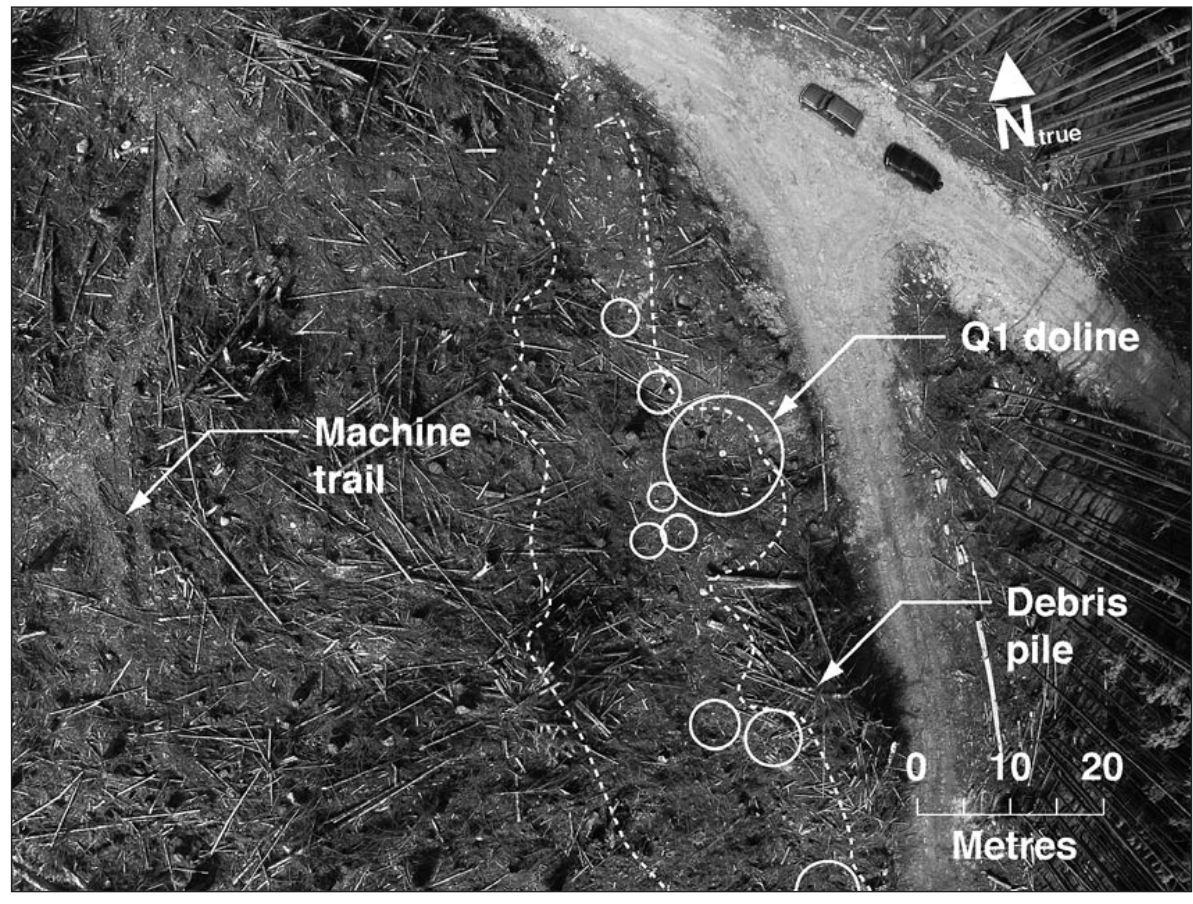

Fig. 5: UAV image of the Q1 doline and the associated depression complex. The dashed white line indicates the larger enclosing karst depression. The solid white lines show the nested depressions, including the Q1 doline, surveyed on the ground in one person-day on June 2012 prior to timber harvesting. 


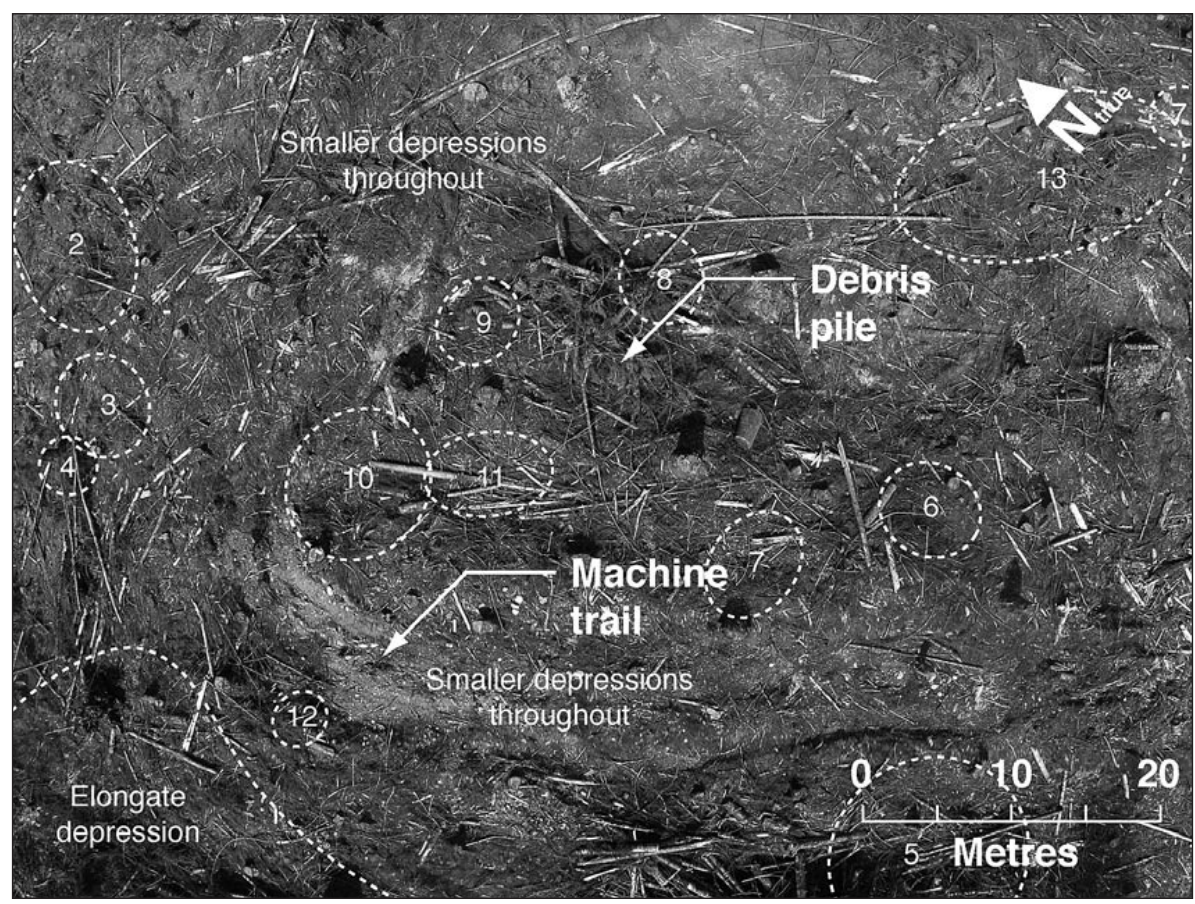

Fig. 6: UAV image of a group of dolines with superimposition of dashed white line outlines of the numbered dolines surveyed on the ground in June 2012.

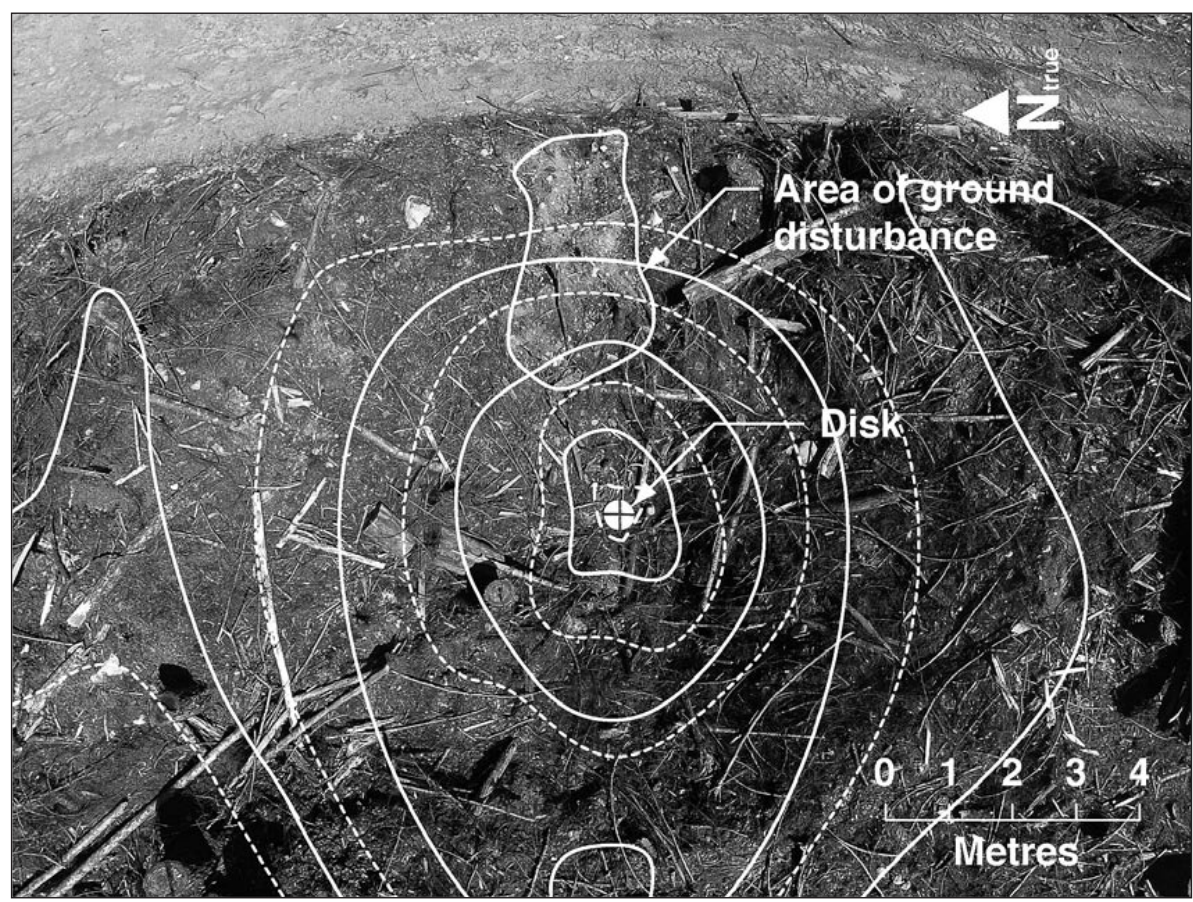

Fig. 7: Low-altitude UAV image of an area of ground disturbance on the inner slopes of the Q1 doline. Aerial images obtained using the mini quadcopter UAV allow for the rapid estimation of harvestrelated ground disturbance. The solid white lines are $1 \mathrm{~m}$ contours and the dashed white lines represent 0.5 m contours.

(FREP) program. The high-resolution aerial images acquired by the quadcopter can easily detect many of the disturbance indicators that are assessed using the FREP procedure. The rapid acquisition of low-altitude high-resolution aerial imagery of karst sites and features offers an opportunity to reduce the costs of conducting effectiveness evaluations for karst using the FREP indicators. For example, the number of mature trees removed from within the Q1 doline can easily be established by counting the number of freshly cut tree stumps showing in the doline on the low-altitude aerial images. Similarly, the aerial images obtained by the quadcopter enable estimation of any harvest-related ground disturbance. 


\section{CASE STUDY 3: BURN AREA}

The Burn Area is a well-developed karst site on which the old-growth forest stands were clearcut in 2000-2001. In August 2009, the site and surrounding karst areas burned as a result of a fire caused by lightning strike. The 200 ha $\left(2 \mathrm{~km}^{2}\right)$ fire incinerated residual tree stumps and organic soil in the clearcut karst areas. Fig. 8 is a ground-based oblique photograph showing the karst site a few months following the fire. This site presents an excellent opportunity to document the effects of intense fire on thinly covered epikarst in a clearcut area, as well as the subsequent regeneration of vegetation over time.

Much of the Burn Area consists of exposed and well-developed epikarst. The many solutionally-enlarged openings and the "fire-cracking" of bedrock projections hamper walking on the karst and present a sig-
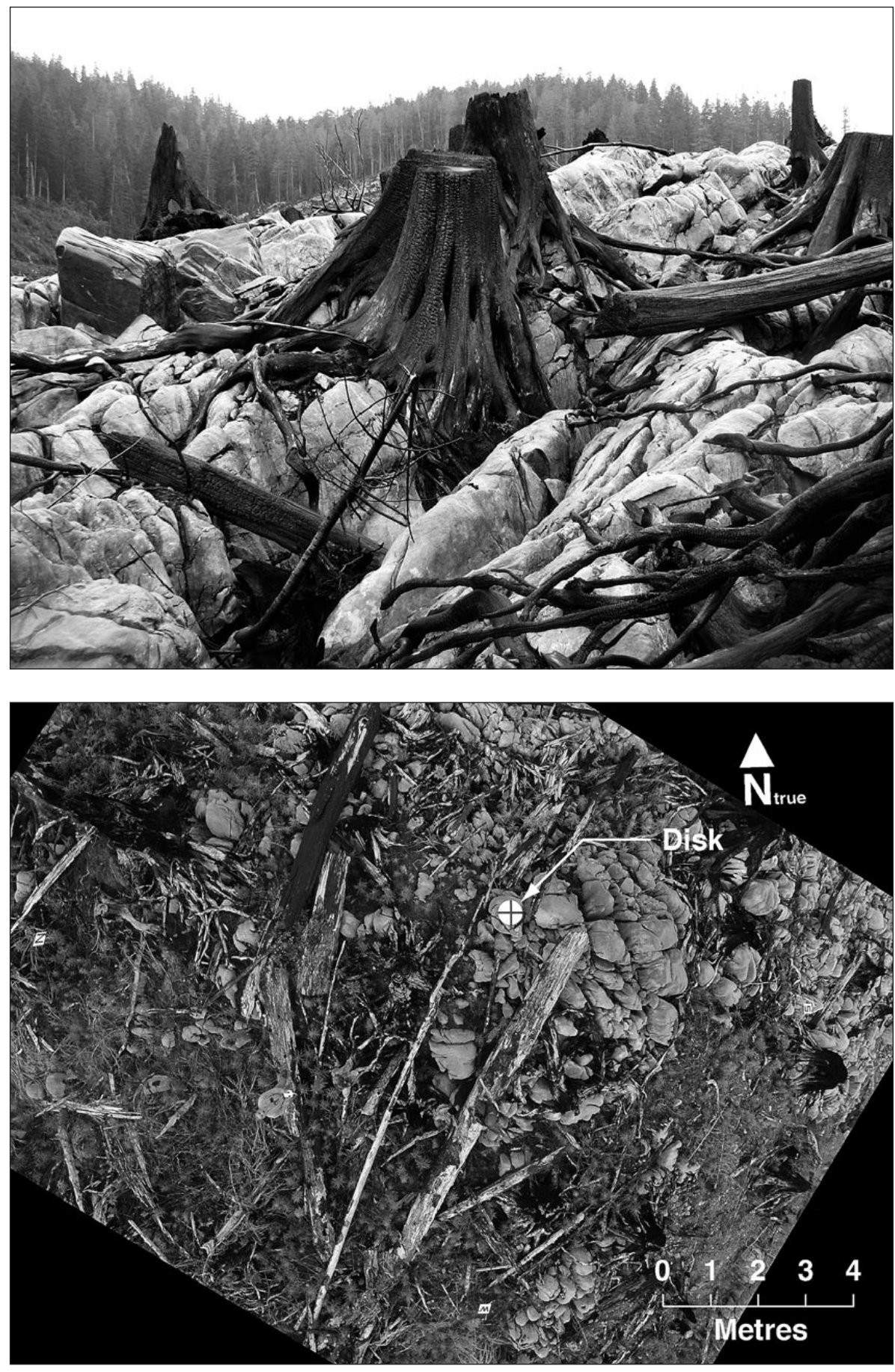

Fig. 8: March 2010 ground-based photo showing part of the Burn Area. The fire occurred in August 2009.
Fig. 9: High-resolution UAV image of part of the Burn Area. UAV-assisted photography makes it possible to conduct cost-effective mapping and ongoing monitoring of disturbed karst sites. 
nificant risk of human injury from falling or tripping. The authors visited the site with the camera-equipped quadcopter UAV, established spatial ground controls, and sent the aerial platform aloft. The results are shown in Fig. 9.

The Burn Area is an example of a case where there is a limited amount of time to document baseline conditions after a severe disturbance at a karst site. Ideally, monitoring should have begun immediately after the fire, but the area is remote and funding for a detailed post-fire impact assessment project was not available. By using the UAV and low-altitude flights over the Burn Area, it was possible to acquire high-resolution, realtime imagery and documentation of site conditions for a modest cost. These images could be used for future study and enable ongoing monitoring. The field trial at this site showed that images suitable for fine-scale mapping of forest vegetation and other groundcover on karst sites could be acquired easily when the quadcopter UAV is flown at a very low altitude. The use of the quadcopter UAV in this application also minimized the need for personnel to move about on a hazardous karst area (Fig. 10).

\section{CASE STUDY 4: PARADISE LOST}

Paradise Lost is a cave system with an underground stream that was discovered and mapped in 1986. The known, normally dry entrances are located at the base of the $70 \mathrm{~m}$ long, $50 \mathrm{~m}$ wide, and 25-30 $\mathrm{m}$ deep entrance doline.
Much of the old-growth forest of the Upper Tahsish Valley karst was clearcut between 1982 and 1986. B.C. lacked specific karst management guidelines and legislation at that time, and little heed was paid to the well-known ability of karst to evacuate sediments from the surface, resulting in soil erosion/loss during and after harvest operations. Portions of the karst in this valley bottom, including Paradise Lost, are covered by significantly thick unconsolidated glacial sediments.

Roads were put in on three sides of the Paradise Lost entrance doline in 1986. The old-growth forest within the doline and its surroundings was clearcut. In the early 1990s, a depression in the cover material (regolith) began to form on the upper northern slope of the doline (Figs. 11A and 11B). This new feature eventually breached the ceiling of the largest chamber within the upstream part of the cave system. It is now possible to view the Paradise Lost entrance doline (Latitude $50^{\circ} 17^{\prime} 16.40^{\prime \prime} \mathrm{N}$ and Longitude $127^{\circ} 7^{\prime} 30.28^{\prime \prime} \mathrm{W}$ ) using Google Earth and other available satellite coverage. This imagery, however, lacks detail and the 'real-time' information needed to monitor the ongoing breakdown and loss of cover material to the subsurface. Also, the karst feature is currently unstable and obtaining such measurements on the ground or inside the unroofed cave chamber would be extremely hazardous.

When the authors visited the Paradise Lost entrance doline site, the roads leading to the site were found to be unmaintained and heavily overgrown. Subsidence of these roads had occurred and in some places small holes

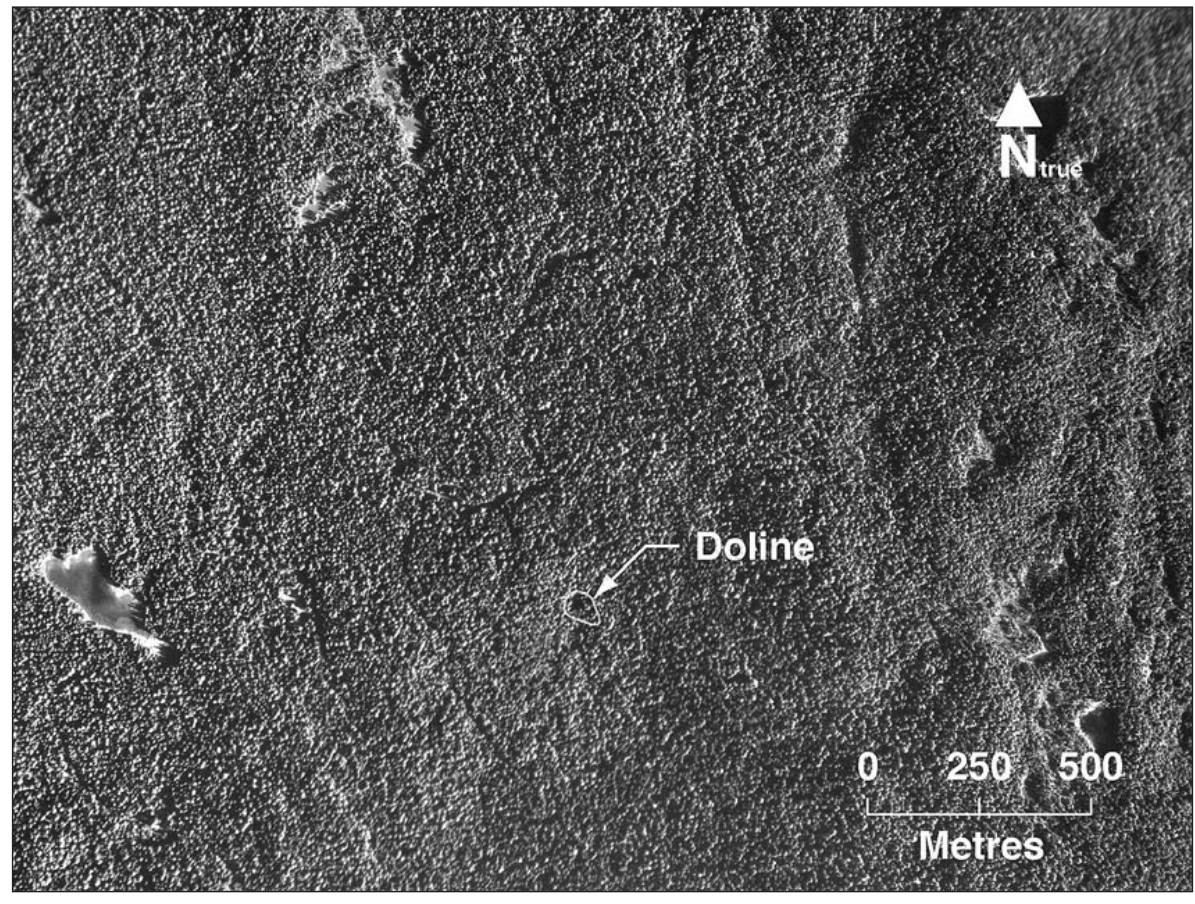

Fig. 10: This high-altitude Province of British Columbia aerial photo shows the Paradise Lost entrance doline area in 1980. Harvesting of the doline and the area immediately surrounding it began in 1986. 


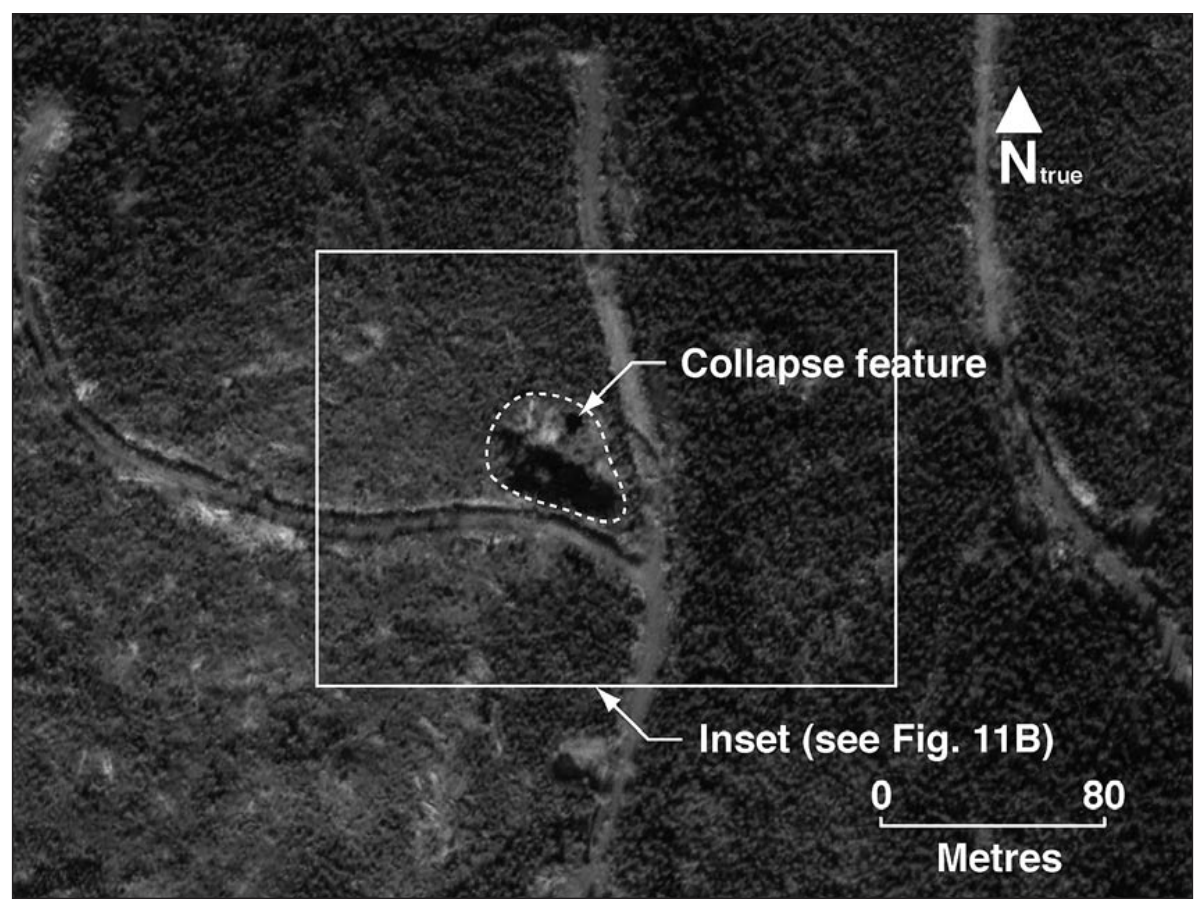

Fig. 11A: The most current Google Earth satellite imagery (dated 2002) shows the Paradise Lost entrance doline and the collapse feature on the sidewall. The dashed white line indicates the doline rim.

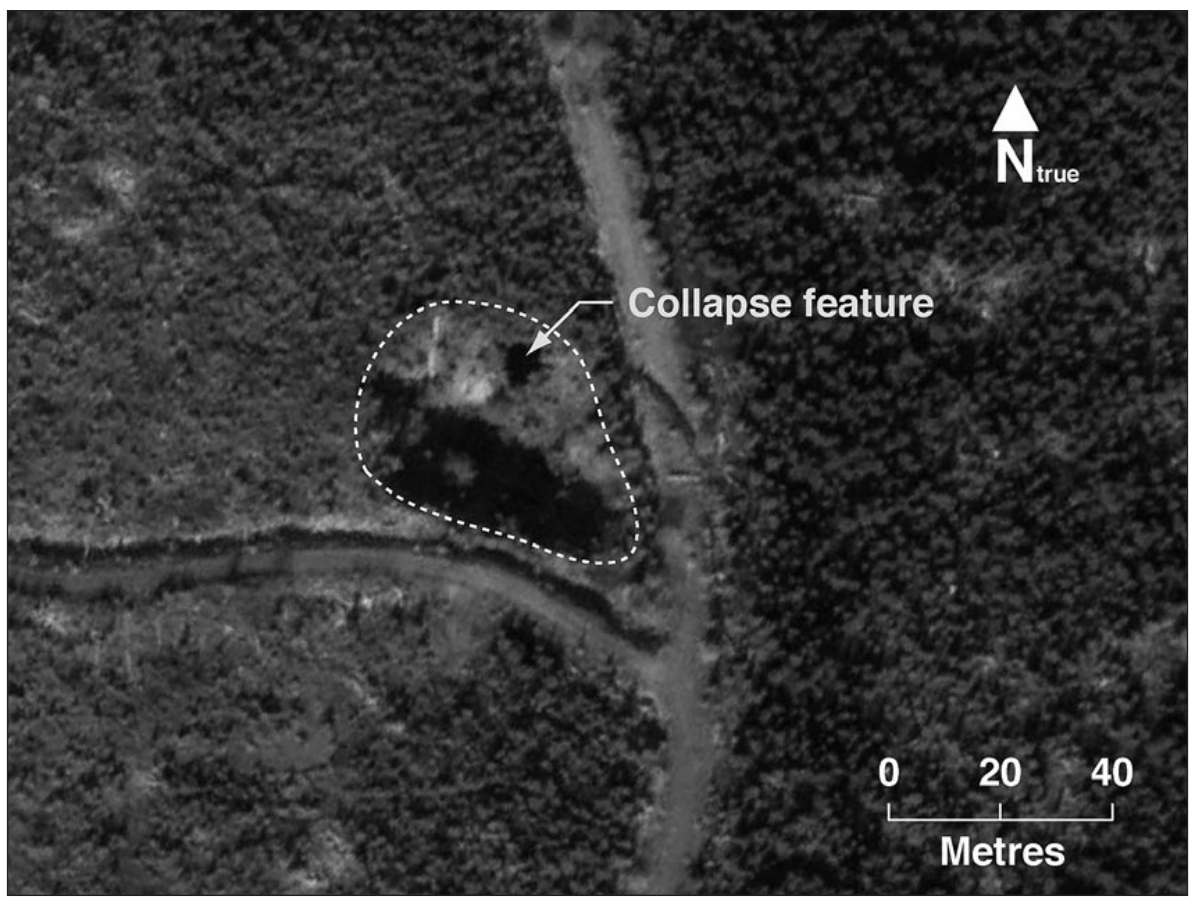

Fig. 11B: Inset area of Fig. 11A with the dashed white line outlining the doline rim.

had opened up in the roadbed. It was therefore decided to walk along the road for the remaining half kilometre to the site, carrying the camera and housing, the quadcopter, radio controller and spare batteries in a small backpack. The aerial platform was flown over and into the collapse feature repeatedly for approximately $5 \mathrm{~min}$ utes. The results are shown in following Fig. 12A, 12B, $12 \mathrm{C}$ and $12 \mathrm{D}$.
This case study illustrates how low-altitude, highresolution aerial imagery captured with a quadcopter UAV makes it possible to inspect and document hazardous or unstable karst sites or features with minimal risk of human injury. The negligible weight and size of the aerial platform allow for easy storing in a small backpack for remote-area expeditions. Also, the images acquired 
are of higher resolution and more recent than the available air and satellite imagery.

\section{CASE STUDY 5: DEVIL'S BATH}

The Devil's Bath is a vertical- and steep-walled collapse feature containing a $110 \mathrm{~m}$ by $120 \mathrm{~m}$ lake. The doline lake is in hydrological continuity with, and connected to, multiple inflow and outflow cave passages and conduits occurring to the northeast and west of the Devil's Bath. Bath Cave, situated on the west side, receives flow from, and recirculates flow to, the doline lake. The main waterfilled passage extension from Bath Cave to the northwest is also connected to the Gorge Caves. This underwater connection has been explored and mapped by diving for a distance of $375 \mathrm{~m}$.
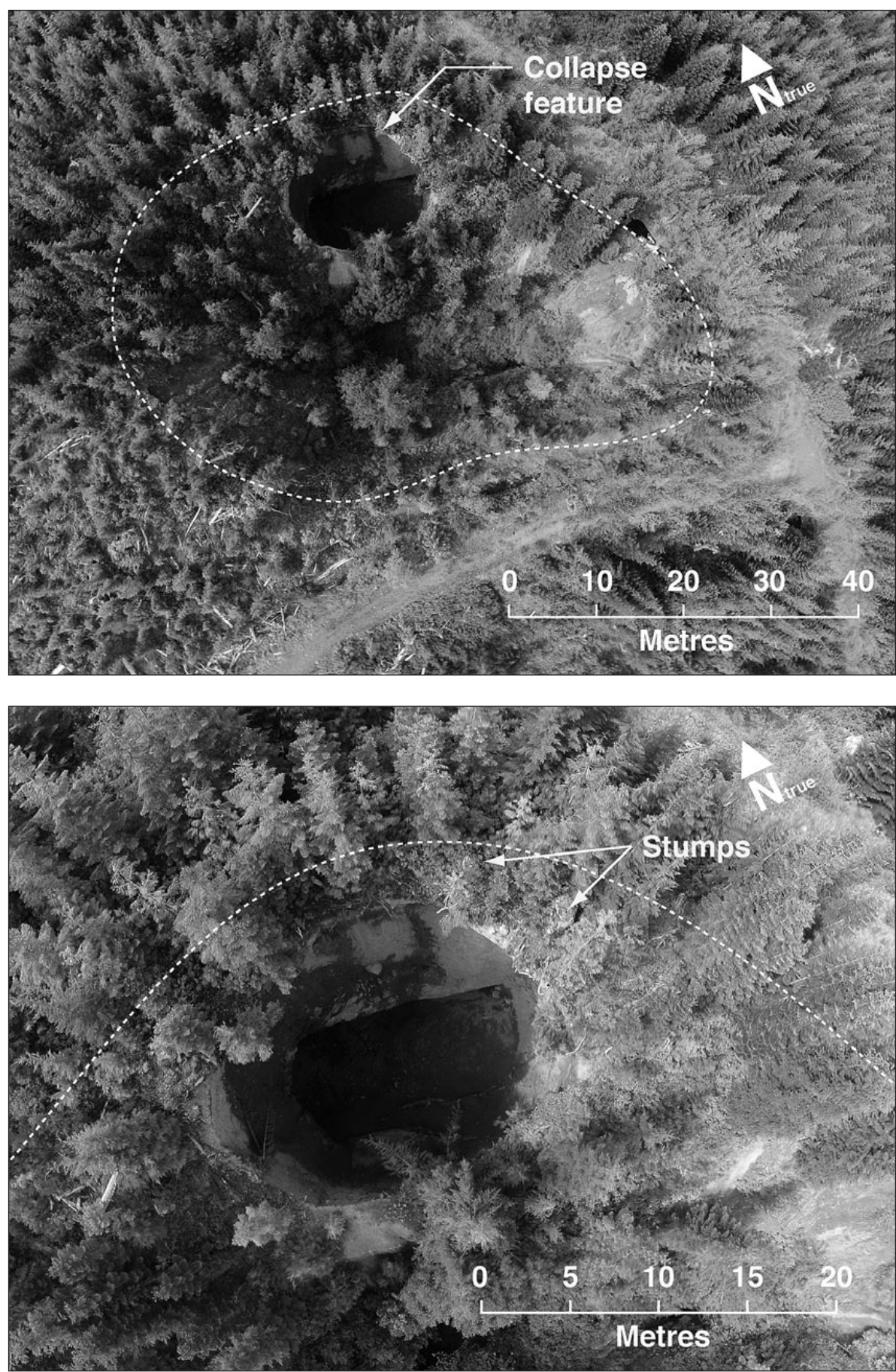

Fig. 12A: UAV image of the Paradise Lost entrance doline with the dashed white line outlining the doline rim.
Fig. 12B: UAV image focusing on the collapse feature. The dashed white line outlines the doline rim. 

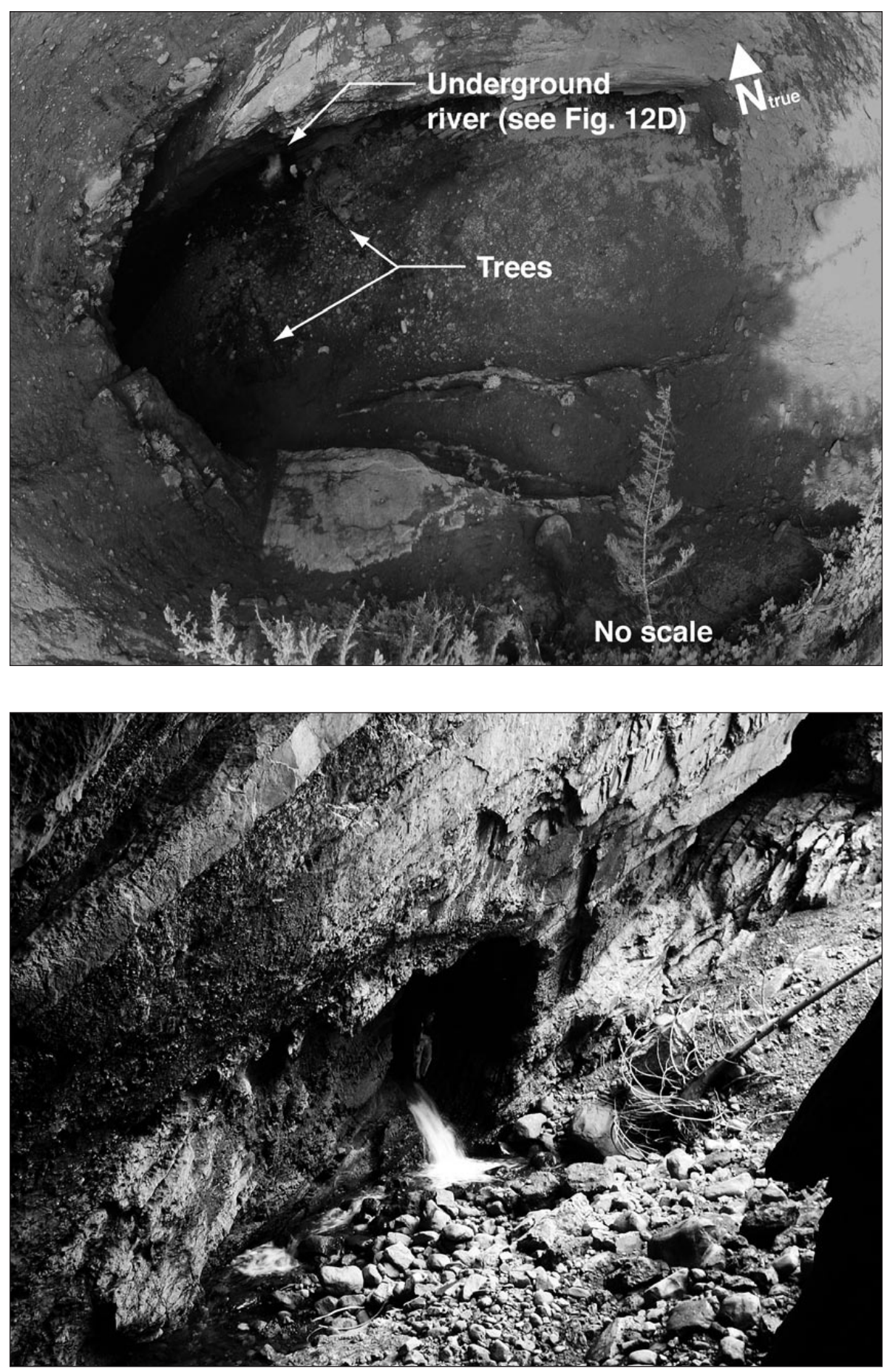

Fig. 12C: UAV image of the collapse feature from the elevation of the rim. These figures show the possible uses of the mini quadcopter UAV to investigate hazardous collapse features and to measure them over time.
Fig. 12D: Ground-based photo of the cave stream viewed from the bottom of the collapse feature.
On the surface, the Devil's Bath feature closely resembles a cenote similar to those found in Mexico's Yucatán Peninsula. ${ }^{5}$ It is a unique and significant karst

\footnotetext{
${ }^{5}$ Cenote is the Spanish language term coined after the Mayan tzonet or dzonot. One of the most famous Mexican cenotes, Chichen Itza, measures $60 \mathrm{~m}$ across with $30 \mathrm{~m}$ high vertical walls.
}

feature on Vancouver Island, as well as at the regional and possibly provincial or national level. ${ }^{6}$ The consider-

${ }^{6}$ The Vermillion Creek collapse doline in the NWT measures $120 \mathrm{~m}$ long, $60 \mathrm{~m}$ wide and $40 \mathrm{~m}$ deep to the waterline (Ford 1997), and is described as the finest example of a doline of this type anywhere in Canada and the United States (Ford 2009). 


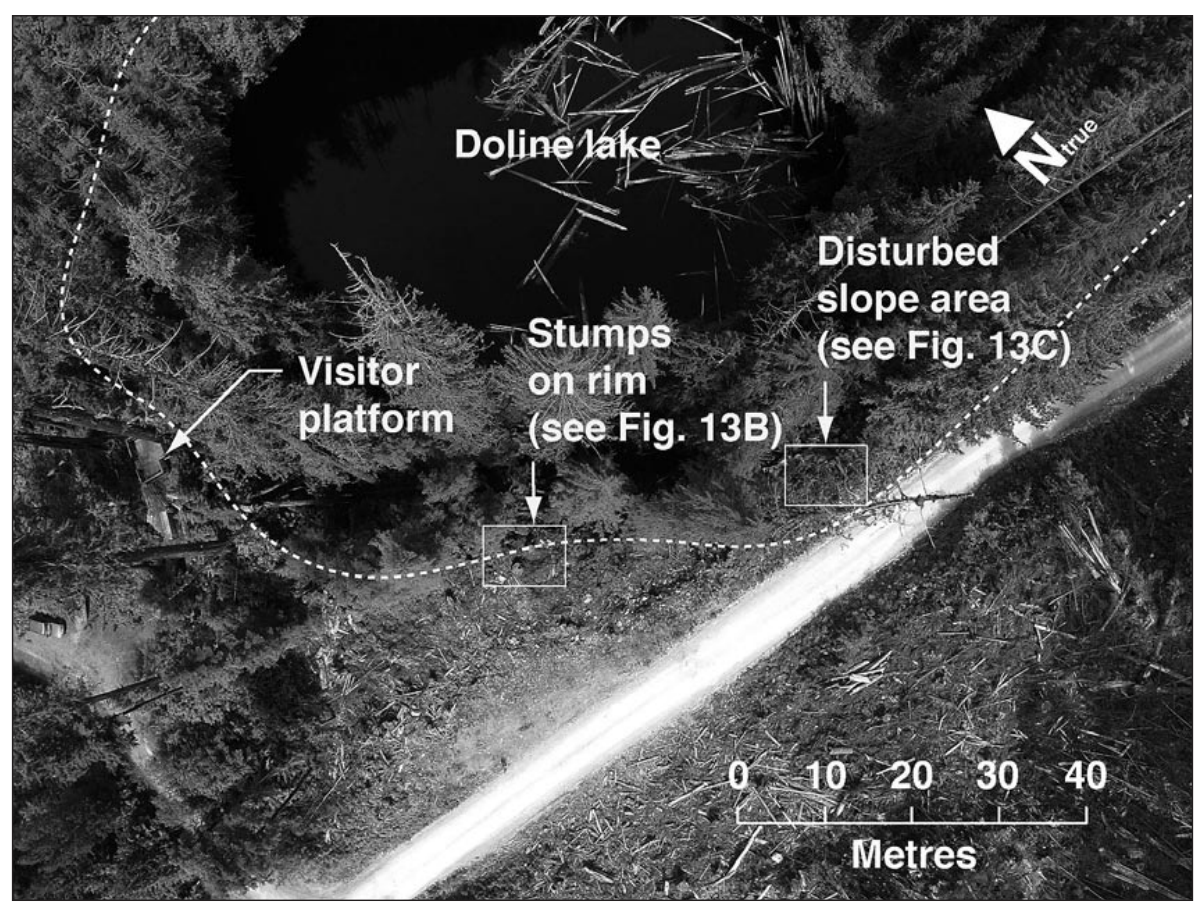

Fig. 13A: UAV image showing part of the area of the 2012 harvesting next to the Devil's Bath doline lake. The dashed white line indicates the approximate doline rim location based on the lowermost continuous slope break. Establishing the postharvest condition of surface karst resource features is now possible with rapid assessments using a mini quadcopter UAV and largescale aerial photography.

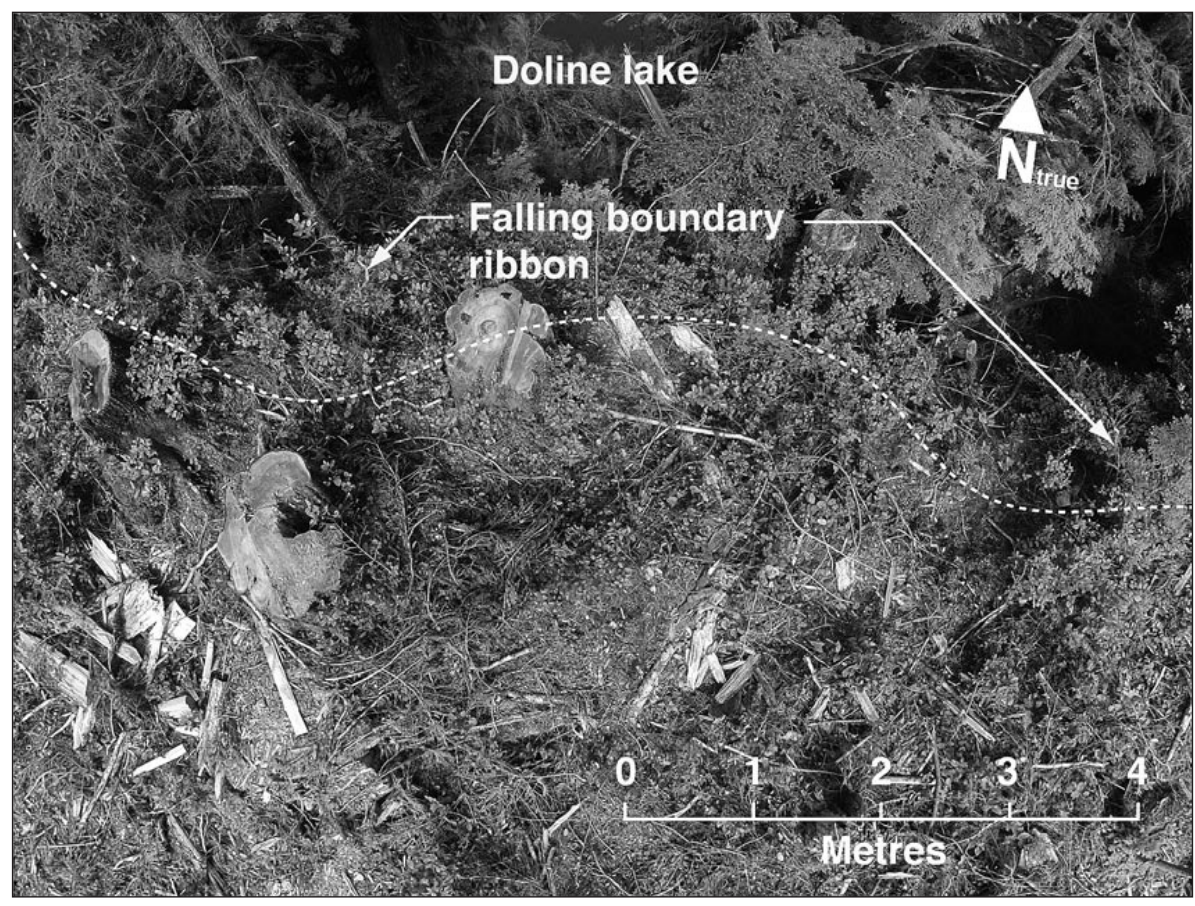

Fig. 13B: UAV image showing the tree stumps on the doline rim. The dashed white line indicates the approximate doline rim location based on the lowermost continuous slope break.

able size and scenic nature of the doline, its origin and evolution, and its relationship to the greater Devil's Bath hydro-geological karst system are of significant interest to both scientists and the public. A trail and platform to view the doline lake were provided initially in 1997 and renewed in 2009.

Large-scale forestry operations within the contributing karst catchment adjacent to the site began in earnest in the 1960s, while lesser amounts of cutting for mining exploration and timber production purposes trace back to the early 1900s. Harvest operations within the greater Devil's Bath site were carried out in ca. 1972, 1981, 1984, 1985, 1999-2000 and 2012.

Built in the 1960s, Alice Lake Main is an active hauling road that passes along one side of the doline. In one area, this road sits directly above cave passages 


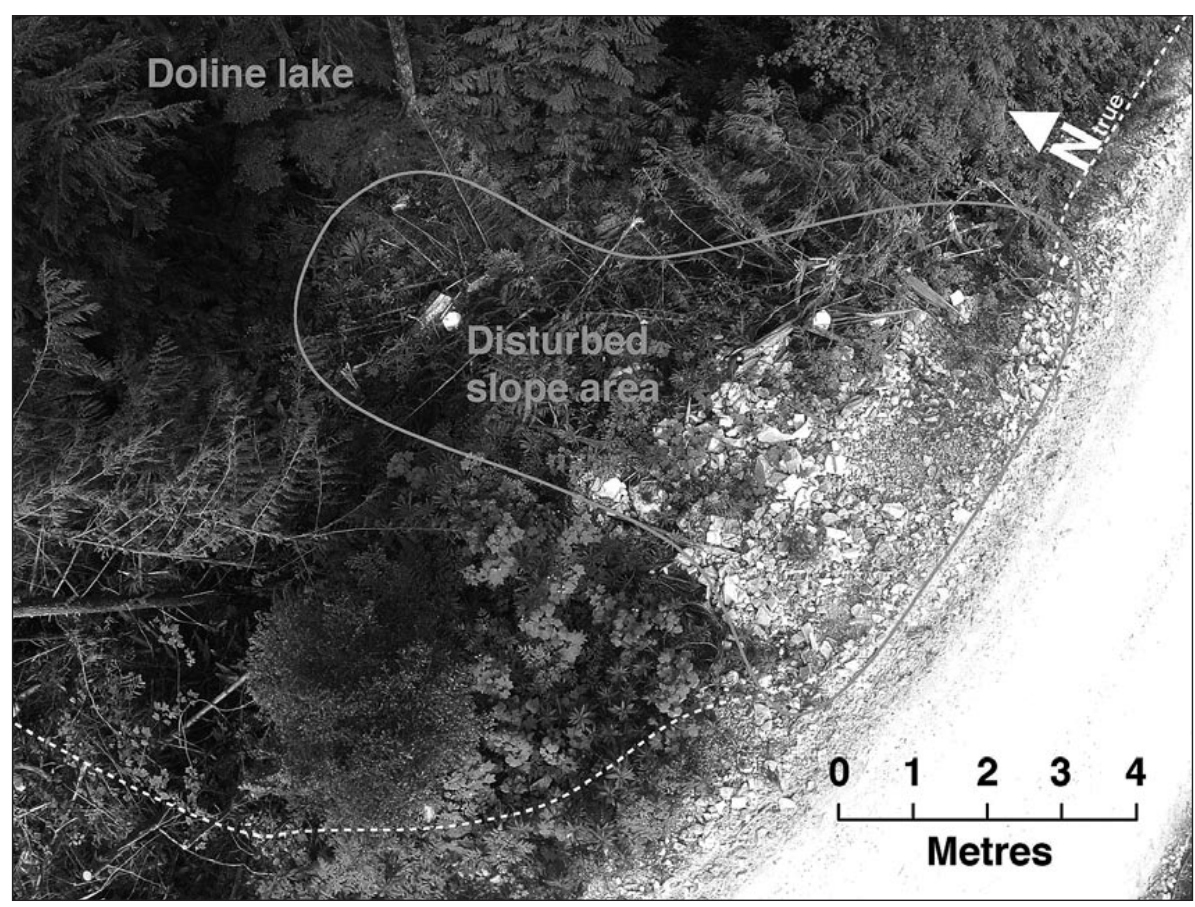

Fig. 13C: UAV image showing a disturbed slope area (raveling road fill and vegetation damage due to snag falling activity). The dashed white line indicates the approximate doline rim location based on the lowermost continuous slope break.

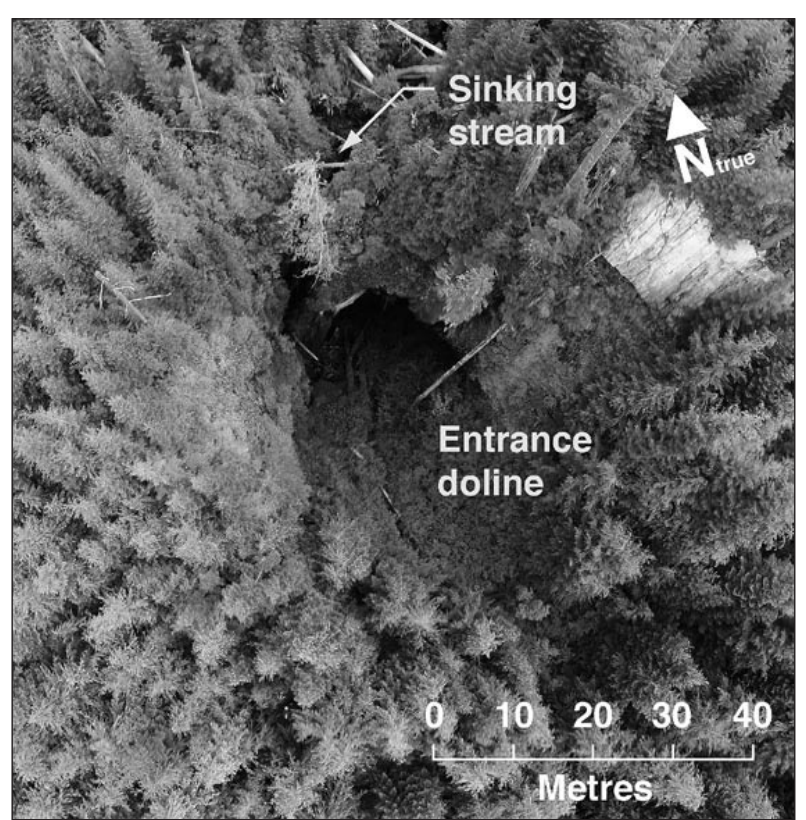

Fig. 14: UAV image of the Glory 'Ole entrance doline. The very short focal length and wide-angle viewing of the GoPro Hero2 camera lens provide a very large coverage area for image capture. This offers the advantage that multiple UAV images are not required to cover the same site.

and chambers that form part of the Devil's Bath hydrogeological system and provide subterranean habitat for three or more fish species.

Harvest operations in 2012 removed about 2 ha of the old-growth forest on the south side of the Devil's Bath do- line. The logging on the site and in the upland karst south of the road is clearly visible from the doline lake viewing platform and from numerous other vantage points within and surrounding the doline (Figs. 13A and 13B).

The aerial images of the Devil's Bath in the context of its immediate suroundings can be used to show how different karst elements at complex sites are related and linked hydrologically. Such images can assist in the interpretation of complex karst sites in order to educate the public or inform forestry planning and management. The imagery can also be used to capture, document, and illustrate the cumulative impacts to this and other important karst sites.

\section{IMAGERY PROCESSING AND STORAGE}

The spatial data obtained from vertical aerial photography acquired with a quadcopter UAV can be validated using accurately surveyed ground control points (GCPs). Images can be geo-referenced or orthorectified to enable proper scaling. Inexpensive software is readily available to transform and correct images for photogrammetric analyses and measurements. Use of the camera with a narrower viewing field may provide better results for photogrammetric analyses and measurements.

\section{STEREO REQUIREMENTS}

The individual high-resolution images acquired by the quadcopter can be stitched together manually using common graphics software to create a larger image of the karst site even if no GCPs are established. The imagestitching software typically identifies and calculates con- 
trol points within areas of neighboring images and uses these points to match the images together and produce a tiled image area.

The very short focal length and wide field of view of the camera lens provides a very large coverage area for each image. This offers the advantage that the quadcopter can be flown below the safe height of $120 \mathrm{~m}$ above the ground and multiple mosaic images are not required to cover the same site. Due to the wide field of view setting used for these test flights, the images are increasingly distorted away from the center of the photograph and are not, therefore, uniform in scale. This can be compensated through cropping and correcting for the lens effects, or use of a camera with a narrower field of view setting. The quadcopter operator can trade on the efficiency of the wide field of view and area per image (see Fig. 14) with orthogonal accuracy of the degree necessary for use in precision mapping within a GIS environment.

Typically large file sizes require significant storage space for images as well as capabilities to reduce image size for future transfer. Many images can be taken during a flight and time is required to sort and select the best images. Therefore, it is best to check images in the field, particularly if in remote areas, so as to secure appropriate image capture.

\section{DISCUSSION}

The previous five case studies demonstrate that the quadcopter UAV-assisted aerial imagery is a valuable new tool for the evaluation and assessment of karst resources, particularly following timber harvesting activities. While the uses and applications of this technology require further exploration the following strengths are apparent:

- Versatility in terms of scale: Multi-rotor UAV-assisted aerial photography allows karst researchers or managers to acquire high-resolution imagery at a variety of scales - from broad 'overviews' to lower elevation photography at finer scales for such uses as detailed mapping of individual dolines or exposed epikarst areas.

- Ability to capture scaled vertical imagery at high resolutions: The quadcopter UAV enables imagery at high resolution providing that spatial ground control points or scales are present in the photographs and that the images acquired with the quadcopter are of sufficient resolution to make detailed measurements of biophysical elements of the karst site (e.g., plants and substrates, surface openings, etc.).

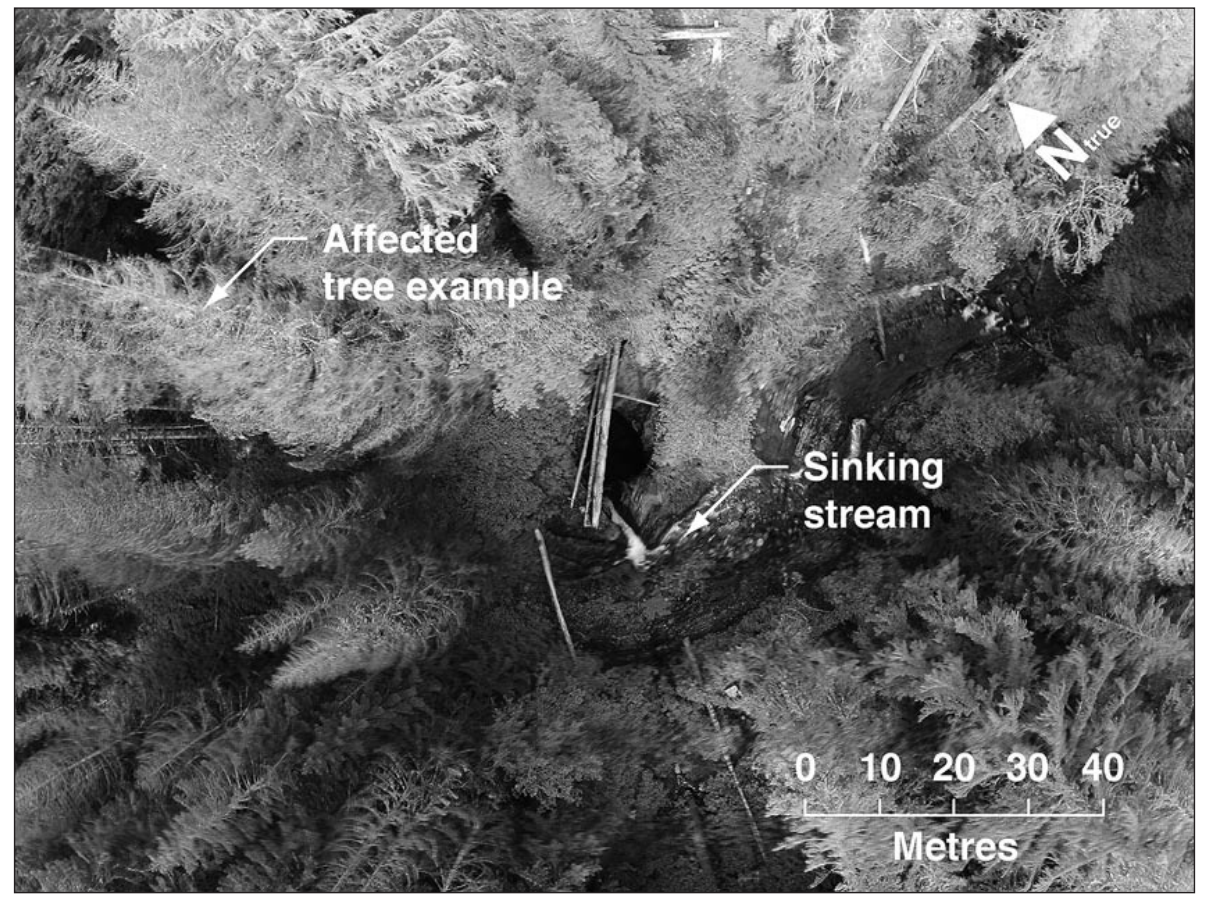

Fig. 15: UAV image shows the developing tree mortality at the Vanishing River site. 
- Ability to capture real-time imagery: The quadcopter UAV can provide karst scientists and management authorities with real-time updates on site conditions during or after natural disturbance events or land use activities (e.g., see Fig. 15).

- Optimal visibility: Lower elevation flights allow the quadcopter to acquire overhead imagery of karst sites that might otherwise be masked by cloud cover or vegetation in the available satellite imagery.

- Speed and cost-effectiveness: The ease and speed with which UAV-supported aerial images are acquired make it possible to monitor many types of karst sites and features with less expense and effort than other methods.

- Inexpensive: Multi-rotor UAV aerial platforms are economical (i.e., about $\$ 1200$ USD for the quadcopter UAV and a high-resolution compact digital camera). One hobbyist UAV aerial platform can be purchased for a price equivalent to that of a single hour of helicopter time at current charter rates.

- Ease of use: Multi-rotor UAVs are relatively easy to learn to fly. It took the authors only a few evening practice sessions to gain sufficient proficiency to take the aerial images used in the case studies. Excellent free web tutorials are available for novice pilots.

- Portable: The compact size of the complete aerial platform makes it easily transportable to remote areas.

- Increased safety margin for field workers: UAV-assisted imagery gives karst scientists and managers the ability to obtain detailed observations of karst features or sites that are unstable, hazardous, confined or operationally active, without risk of resource damage or human injury.

- Highly manoeuvrable: An open area of $100 \mathrm{~cm}$ wide or less is needed to launch and retrieve the aerial platform. Within-canopy and cave entrance flights are possible with some practice. The authors have made some limited successful attempts to fly the quadcopter inside larger cave entrances under manual control.

- The authors were easily able to hand-launch and land the vehicle with complete control.

- Low impacts on karst resources and karst environments: UAV-assisted imagery can be used to inspect or document some very sensitive karst sites or features where ground-based access might constitute an unacceptable level of disturbance, either to the features themselves or their surrounding environment. The quadcopter generates less noise and rotor wash than a manned helicopter in low-altitude flying or hovering positions, thus minimizing the potential for wildlife and/or vegetation disturbances. The battery operation of the quadcopter reduces the risk of accidental ignition of vegetation and other potential fuels at dry sites.

\section{LIMITATIONS OF THIS QUADCOPTER UAV AERIAL IMAGERY TECHNIQUE INCLUDE:}

- GPS signal reception: The built-in GPS may not work in closed karst features such as deep, steep-sided dolines, owing to an inadequate number of available satellite signals. With practice it is possible to fly the UAV without GPS navigation capability, but the ability of the unit to hover in a stationary position is compromised.

- Forest canopy and shrub layer obstacles: Forest canopy does not interfere with the GPS controls as sometimes happens with older, less sensitive GPS receivers, but low branches or a high shrub layer may cause the UAV to crash.

- The "Jello" effect: A problem often reported by recreational users of UAV-assisted photography is the so-called "jello" effect, or image distortion resulting from vibration in flight during video recording. Using a gimbal mount and/or vibration isolation accessories can reduce the vibration effects of the vehicle in flight.

- Image distortion: In the case studies above, the highresolution compact digital camera was used in stillimage capture mode with the $170^{\circ}$ field-of-view setting, resulting in some distortion toward the edges of the photograph. Inexpensive software such as PTLens [http://epaperpress.com/ptlens/] is available to correct for the distortion, but it requires research, downloading and some skill acquisition for use with the proper settings.

- Weather factors: The quadcopter UAV performed reasonably well in moderate wind speeds. It has also been tested successfully in drizzle for short test flights. Nevertheless, very high winds or rain can make it more difficult or impossible to acquire images over a karst site.

- Depth perception: Depth perception can be hampered as the quadcopter gets further away, and it could become difficult to determine whether the UAV is actually over the target. This problem may be corrected using a first-person viewing (FPV) system.

- Battery time: Batteries can be recharged using an inverter plugged into a vehicle cigarette lighter, but recharging LiPo batteries must be monitored and recharging batteries may not be possible in situations where the work is carried out far from a vehicle. 


\section{CONCLUSIONS}

Field trials have shown that a relatively inexpensive radiocontrolled, mini quadcopter UAV mounted with a highresolution compact digital camera can be used to rapidly gather detailed low-altitude aerial images of surface karst resources. Future experimentation using the quadcopter UAV for photogrammetric analyses of sensitive karst sites and features of high conservation value to produce accurate digital elevation models for these sites has already been planned. In future, acquired imagery could be incorporated into the range data provided by terrestrial laser scanning. It is concluded that UVA-assisted highresolution digital photography is a promising new tool for karst researchers and managers.

\section{ACKNOWLEDGEMENTS}

This article was written in the course of doctoral study, which was partly co-financed by the European Union through the European Social Fund within the framework of the Operational Programme for Human Resources Development for 2007-2013 (development priorities promoting entrepreneurship and adaptability; directions priority, 1. 3: Scholarship Scheme). The authors gratefully acknowledge this support.

The authors also wish to thank Nadja Zupan-Hajna, Pavel Bosák, Bill I'Anson and James Reddicopp for reviewing the manuscript. Their thoughtful feedback and helpful comments are much appreciated.

\section{REFERENCES}

Bošnak, M., Matko, D., \& S. Blažič, 2012: Quadrocopter control using an on-board video system with offboard processing.- Robotics and Autonomous Systems, 60, 657-667.

Fischl, P., 1992: Limestone and Dolomite Resources in British Columbia.- B.C. Geological Survey Branch, Open file number: 1992-18.

Ford, D.C., 1997: Principal features of evaporite karst in Canada.- Carbonates and Evaporites. 12(1), 15-23.

Ford, D.C., 2009: Mapping Known and Potential Karst Areas in the Northwest Territories, Canada.- Environment and Natural Resources, Government of the Northwest Territories.

Griffiths, P. A., 2013: Managing and remediating forested karst landscapes in B.C.: an ounce of prevention is worth more than a pound of cure.- B.C. Forest Professional, 20(2), 18.

Griffiths, P.A., \& C. Ramsey, 2006: The Digital Karst Status Map for Coastal British Columbia.- Unpublished report.

Moore, R.D., Spittlehouse, D.L., Whitfield, P.H., \& K. Stahl, 2010: Weather and climate.- In: Redding, T. (ed.) Compendium of Forest Hydrology and Geomorphology in British Columbia. Forum for Research and Extension in Natural Resources (FORREX), pp. 47-84, Kamloops.
Murray, J.C., Neal, M.J. \& F. Labrosse, 2012: Development and deployment of an intelligent kite aerial photography platform (iKAPP) for site surveying and image acquisition.- Journal of Field Robotics, 30(2), 288-307.

Roßmann, J., 2009: High-detail local aerial imaging using autonomous drones.- Presented at the $12^{\text {th }}$ AGILE International Conference on Geographic Information Science. 2-5 June 2009, Leibniz University, Hannover, Germany. [Online] Available from: http://www.agile-online.org/Conference_Paper/ CDs/agile_2009/AGILE_CD/pdfs/113.pdf

[Accessed 11 ${ }^{\text {th }}$ June 2014]

Vyse, A., Bendickson, D., Hannam, K., Cuzner, D. \& K.D. Bladon, 2010: Forest practices.- In: Redding, T. (ed.) Compendium of Forest Hydrology and Geomorphology in British Columbia. Forum for Research and Extension in Natural Resources (FORREX), pp. 111-131, Kamloops. 